\title{
Northwest Africa from colonial to global shipping
}

\author{
Daniel CASTILLO, César DUCRUET
}

Pre-final version of the chapter published in Ducruet C. (Ed.) (2017) Advances in Shipping Data

Analysis and Modeling. Tracking and Mapping Maritime Flows in the Age of Big Data, Routledge

Studies in Transport Analysis, pp. 397-413.

Despite the importance of ports and seaborne trade for the African economies, literature on the evolution of African port systems is not in the front line of research (Debrie, 2012; Cherfaoui and Doghmi, 2005; Dickson, 1965; Hoyle, 1967; Mohamed-Chérif and Ducruet, 2016).Considering port geography as a whole, the proportion of articles written about Africa had dramatically decreased from about $20 \%$ in the 1950 s to less than $5 \%$ in the 2000 s, but had witnessed an increasing trend in the early 2010s (Ng and Ducruet, 2014). However, a number of scholars promoted historical approaches to port studies from an individual case perspective (Castillo Hidalgo, 2014; Olukoju, 2004; Peterec, 1967). A key issue is to explore the degree of stability of port hierarchies and maritime networks over time, namely from the colonial age up to the first stage of global container shipping. It could be argued that colonial dynamics and path-creation processes reinforced permanent effects on seaborne flows for the African ports, as underlined in early spatial models of port system evolution based on the cases of Ghana and Nigeria (Taaffe et al., 1963), although such models focused more on coastal and inland dynamics than on seaborne flows.

Thus, the main port functions and regional economic specialization promoted the emergence and consolidation of self-reinforcement effects (Martin and Sunley, 2010) on African ports, which were tied to inland transport infrastructures created to support economic extraction processes. Hence, the dynamics of seaborne trade remained almost unchanged from the late nineteenth century up to the last third of the twentieth century (UNCTAD, various issues).

This chapter deals with an analysis of the evolution of ports and port systems in Northwest Africa from 1880 to 1972 . The chronological period studied runs from the first international shipping revolution (steamship navigation) to the first global wave of containerization (Guerrero and Rodrigue, 2014). We shall demonstrate how regional seaborne flows over time and how port hierarchies changed or remained unchanged in a historical perspective. It is important to note the role played by the African ports in the overall process of port reform that began in the second half of the nineteenth century (Kaukianen, 2012).The nature and 
evolution of regional economic structures -mainly south of the Sahara- delayed the modernization of ports and it was a decisive obstacle to economic development in terms of decreasing transaction and transport costs. In this chapter, we will expose the main arguments that explain how this technical gap was motivated by the weakness of local capitals and the colonial policies developed by the imperial nations.

In this study, we have used the United Nations' geographical delimitation of territories to define the explored area of northwest Africa (for other analyses of transnational port systems, see Chapters 5, 8, 9, 11, 19, 23, and 24 on Taiwan Strait, Black Sea, Arctic, Mediterranean, USSR, and Indian subcontinent areas). Thus, we have collected data from all countries (former colonies) and territories (i.e. Spanish possessions) running from Tunisia to Angola. The first issue to bear in mind is the existence of historical port hierarchies where a central seaport concentrated most of the cargo handled and on the other hand, the number of vessels calling the country. As will be demonstrated later, these central ports were complemented by secondary ports. Most of them functionedsimilarly to Hoyle's description (1967, p. 65) of the East African ports:

"The smaller ports, where the tonnages of oil products imported are much smaller and where exports outweigh imports by a wide margin. This pattern reflects the fact that the primary function of both these ports is the export of a single primary product from the immediate hinterland, an area which does not constitute in either case a very important market for imported goods".

Under this scheme, from the 1970s cargo handled at regional ports (both central and secondary) featured a massive predominance in cash-crop exports (peanuts, palm-oil, vegetables, wheat, wax, rubber, coffee, cocoa, timber), mining commodities (phosphates, iron ores, copper) and oil products (crude oil and derivates). By contrast, imports were usually less important in volume but not in value: industrial manufactures, machinery, clothes, building materials, staples, etc. In the case of imported goods, a number of great seaports absorbed most of them and we provide compelling evidence on the lack of port development south of the Sahara during the first half of the twentieth century that contributed to economic stagnation in these regions. Otherwise, great seaports concentrated seaborne trade and promoted urban growth through the consolidation of a primate city, which hampered regional integration (Seck, 1970; see also the mercantile model of Vance, 1970).

In this chapter, we have collected data from Lloyd's List to rebuild shipping patterns across Northwest Africa between 1900 and 1970. This chronology is representative for the whole covered period and it permits a comparison between different primary sources. In particular, the Shipping Index provides a snapshot of global and regional maritime activity based on the 
last inter-port movement of every registered vessel. We then compiled port throughput data from a number of archival sources in France, United Kingdom, Senegal, Spain, Portugal and other African countries between 1913 and 1972. Further efforts are being made to palliate the lack of information for all the region's ports and countries1. Using multiple shipping data sources also represents a challenge in terms of potential gaps and overlaps which may be caused by different measurement units and methods.

\section{The waves of port modernization in Northwest Africa}

The first consideration of note is the clear difference between the African Mediterranean ports and the Atlantic ports south of the Sahara. If we compare both regions, in terms of volume of cargoes, maritime connectivity and historical development, the Maghreb ports were well integrated into the Mediterranean maritime network during the late nineteenth century. Nevertheless, most colonial seaports in the West African colonies were poorly equipped in terms of modern infrastructures: berth posts, jetties, warehouses, bunkering facilities, intermodal connections, etc. If we observe the charts (see Tables 23.1 and 23.2) denoting port activity before 1950, we could argue that these point to an evident lack of port development. Comparing these charts with port throughput figures confirms the deficiency of port development in these regions. Yet, a number of large seaports constitute interesting exceptions, at least for the first half of the century, such as Dakar, Lagos, Accra, and Matadi. These ports retained important commercial functions and they operated as regional gateways for their hinterlands. They basically contributed to the cash-crop revolution in the late nineteenth century (Austin, 2015) which triggered the expansion of external trade and the construction of inland transport infrastructures, mainly colonial railways (Chaves et al., 2015). Hence, key to the understanding of the evolution of regional seaborne flows is the evolution of regional exports that marked the configuration of trade. The colonial economic extroverted system promoted this trend and how transport infrastructures were to evolve in a linear way (Mohammed-Chérif and Ducruet, 2016).

[Table 23.1]

Table 23.1 summarizes the main driving factors that affected port evolution in general terms. We have included a number of elements that helped to explain how endogenous and exogenous events transformed the port systems in our study area. The first stage (18801913 ) is marked by the consolidation of colonial rule and the expansion of international steam navigation. During this period, port infrastructures were scarcely developed in most

\footnotetext{
${ }^{1}$ A complete free access online database for African ports from 1880 up to 2016 is being completed. We expect that it will be available in its provisional first version by November 2017.
} 
countries. On the eve of the Great War, ports and railways began to expand (i.e. Dakar, Conakry, Accra) and the main direct consequence was the rise of external trade and the consolidation of colonial economic and political institutions.

The second period is characterized by interwar instability. Improvements in shipping (transition from coal to fuel) required further changes in port infrastructures, which were hampered by international crises. The most important issue was the emergence of Casablanca as the world's main phosphate export port in the early 1920s. As we showed below, Casablanca represented an interesting example of mega-concentration in terms of volume and value of seaborne trade in Africa. On the other hand, before World War II, most regional ports expanded (i.e.: Lomé, Douala, Cotonou, Matadi) as a consequence of the growth of export sectors.

From 1946 to 1960 an important phase of port expansion (throughput, connectivity) takes place throughout the African continent. Several major events such as the first Suez crisis, the independence processes, and a conjuncture of regional instability characterized this transitional stage. In the case of the Suez crises (1956-1975), the deviation of the new generation super-tankers from the Persian Gulf routes to the Atlantic stopover ports such as Cape Town, Dakar, and Las Palmas challenged the efficiency of port infrastructures and the organizational capacity of other port communities. Further consequences of the Egyptian crises permanently affected regional bunkering ports which retained a part of these traffics in a context of enlarged vessels and the entrepreneurial policies of scale economies (Kaukianen 2012, pp. 67-68). The institutional flexibility of port institutions, the state of infrastructures and the quality of port services were key factors which help to explain the retention of these stopover traffic at these ports.

On the other hand, the French FIDES plan launched after 1947, which massively invested in infrastructure modernization in French West Africa (FWA), resulted in the improvement of Dakar's port infrastructures and the construction of Abidjan port. Both ports absorbed almost 60 percent of global investments in port infrastructures for the whole federation between 1947 and 1957.

The last period analyzed (1960-72) coincides with the onset of the second global shipping revolution whereby African ports faced important obstacles in terms of financial capacity. The first containerized cargo in Africa was handled in 1972, reinforcing established port hierarchies and shipping patterns based on bulks and non-containerized cargoes. The global dynamics of progressive decline of seaborne freights analyzed by Ekberg, Lange and Merok (2012) did not reach most African countries due to trade tax restrictions, the state of regional infrastructures, the structure of seaborne trade and the entrepreneurial policies 
developed by the global shipping liners. These conditioning elements and mainly the latter aggravated during the 1980 decade. By 1990 UNCTAD states:

"There is considerable evidence that this "escalating" structure of freight rates is due to the arbitrary pricing policies of liner shipping cartels that charge what the traffic will bear. Nonetheless, their effect is to create a bias against further commodity processing in developing countries (...) The deterioration of ports and related infrastructures also plays a key role" (UNCTAD, 1990, p.52)

Nevertheless, during this last period, new commercial ports like Abidjan emerged and other specialized ports such as Bonny, Escravos (both in Nigeria) Ghazaouet, Arzew, Port Gentil, Cabinda, Kenitra or Bedjaia notably expanded. These ports were devoted to crude oil and refinery activities and their throughput increased at the same pace as that of global demand up to the 1973 crisis. The massive exportation of crude oil during the early 1970s from emergent ports in the Gulf of Guinea represents a new phase of regional evolution.

Furthermore, the analysis of port indicators reveals the configuration of port hierarchies which experienced self-reinforcement effects due to the centrality and predominance of great imperial seaports, at least for general cargo. Dobusch and Kapeller (2013, pp. 298-300) have proposed a number of elements that help to explain how major ports retained their key functions over time. Mainly, based on their approach we argue that the learning and expectation effects (memory effects, habits, routines, historical trends, etc.) in imperial seaports such as Dakar, Algiers, Casablanca or Lagos encouraged port activity, their regional centrality and the economic clustering processes that occurred during the colonial period and this trend strongly remained during the postcolonial Age. Moreover, the institutional choice made by the colonial powers promoted the consolidation of port hierarchies but lockin processes too. A relevant example could be found in Senegal (and subsequently the FWA) and French Morocco. In both cases, colonial institutions promoted the creation of an imperial seaport to provide support for colonization and then the effective exploitation of human and natural resources from the hinterland. The establishment of the first port of Dakar during the 1860s promoted its regional importance (Ba et al., 2013). The port articulated the inland transport network from the whole FWA, and as a consequence, seaports in Guinea, Benin (formerly Dahomey), and the Ivory Coast were not developed. The lion's share of investments occurred in Dakar during the first decades of colonial occupation and then, in the aftermath of World War II massive investments were made in other infrastructures like in Abidjan. The case of Casablanca is the most impressive as we shall see. From the establishment of the French Protectorate in Morocco in 1912, the port of Casablanca began to increase its influence. After the Great War, the phosphate revolution in Morocco changed the maritime façade of the country and the concentration process began. By 1929, the port of Casablanca handled nearly 80 percent of Moroccan external trade in 
volume and value (Suárez and Maziane, 2014). Such a concentration of port activity was mainly a consequence of political conjunctures, in addition to other factors such as natural conditions or the financial capability of each government. In the next section, we will provide an analysis of port traffics and the configuration of historical hierarchies.

\section{The historical evolution of port traffic in Northwest Africa}

\section{Port hierarchies}

Based on a historical database of port throughput volumes by maritime façade between 1913 and 1972, we analyze cargo distribution as well as port specialization. Although the completion of this database is still underway, especially to include better coverage of the former British colonies, this analysis reports on four selected years $(1913,1938,1955$, and 1972), each of them corresponding to a relatively stable conjuncture from the eve of the Great War to the first decade of political independence in most countries included in the study. Then, referring to Castillo and Valdaliso (forthcoming) we propose a taxonomy of ports based on their throughput volume and evolution:

- Leading ports: ranking among the top five in the early periods analyzed and remaining on top throughout.

- Declining ports: initially high-ranking but lost ground and became secondary.

- Emergent ports: did not exist in the early years but climbed to relevant positions.

- Secondary ports: played an ancillary role during the entire period under analysis.

Table 23.2 presents the top 20 ports ranked by throughput for the selected years. The first column (1913) with the notable absence of Lagos, Freetown and Accra, represented an overall economic expansion on the eve of the Great War. Bearing in mind that figures collected from archival sources could be not entirely accurate (lack of figures for a number of ports), there is little doubt that the predominance of Algiers is confirmed. Located in North Africa, the top five operated as commercial gateways, coaling stations (mainly Oran) or phosphate export centers (e.g. Sfax). The main Canary Island ports - Las Palmas and Santa Cruz de Tenerife - enjoyed important positions thanks to their logistical functions as coal suppliers (Suárez 2004). It must be noted that Saint Vincent (Mindelo) had lost importance as stopover port and by 1913 the port began to compete with the recently inaugurated commercial port of Dakar (1910). This was triggered by the replacement of Mindelo as a port of call for the Italian shipping lines to Brazil and Argentina and the rerouting of this traffic to the port of Dakar, where Italian coaling companies were also established. A number of smaller ports deserve attention as well, such as Matadi and Douala (the main port of the 
former German colony of Cameroon), specialized in palm oil, palm kernels, and timber. External trade value at Ghanaian ports for instance grew impressively before the Great War from $£ 4,434,535$ in 1907 to $£ 9,908,613$ in 1913 . Complementary figures on port calls confirm such a trend for Ghana during the same period, while the gross tonnage of vessels calling at Gold Coast ports increased from 560,578 tons (1896) to 1,526,048 tons (1913), representing an average growth of 62.3 percent (Colonial Reports of the Gold Coast, Colonial Office, various issues). Olukoju (2014, p.125) found compelling evidence of a sustained growth of throughput in the wharves (Iddo, ljora, Apapa) of Lagos during the period 1919-29, but overall figures must be tested through the analysis of the Blue Books of the Colonies or similar sources.

[Table 23.2]

Figures for 1938 represent interesting changes in port hierarchy. The emergence of Oran, Annaba (Bône), Casablanca and Dakar and the stagnation of Algiers are some of the main developments. Phosphate exports expanded in Algeria and Morocco, while the fall of the Canary Island ports is directly attributable to the outbreak of the Spanish Civil war and the deviation of vessels to Dakar for bunkering activities. Previously regional secondary ports (but leading ports for the colony), such as Matadi, exhibited rapid growth (i.e. over half a million tons). By 1955, port hierarchies remained relatively stable and Casablanca reached the first rank. The mid-1950s were characterized by an overall growth of port throughput (Table 23.3). An example of this is the impressive growth of Conakry that began in 1953 with massive iron-ore and bauxite exports (80-85 percent of the country's entire exports during that decade). Other key aspects include the aforementioned emergence of Abidjan, partly to exploit the economic resources of the Gulf of Guinea (Rougerie 1950, p. 753). The opening of the Vridi Canal in early 1951 and other works boosted throughput from 215,256 tons in 1938 to 692,673 tons in 1951. Abidjan thus superseded the old wharfs of Grand Bassam and Port Bouët which had been the main commercial ports of the colony until the late 1930s (Direction du Port d'Abidjan, 1955). Another important event that marked the further evolution of the regional port system was the modification of Dakar's hinterland. In 1934, the Ivorian railway reached Bobodioulasso (Burkina, former Upper Volta); by 1956 it extended to Ouagadougou and to Niger in 1958. Thus, Abidjan became a vital gateway for land-locked territories during the second half of the 1950s, causing important changes to historical trade patterns in the context of the balkanization of the FWA. Meanwhile, Santa Cruz de Tenerife's throughput expansion related to the growth of world oil markets due to the existence of a refinery close to the port that was inaugurated in November 1930.

The last column introduces interesting shifts within the port hierarchy. This was the most complete year with 67 ports. New ports had emerged to occupy some of the top ten positions and other formerly leading ports had dropped. The key factor was the introduction 
and expansion of oil activities at these ports. The Nigerian port of Bonny climbed to the top thanks to the discovery of oil deposits in the Niger's Delta. The next four places were occupied by oil-related ports, with the emergence of Arzew (Algeria) and La Skhira (Tunisia). Only Casablanca retained its position. A number of bulk export ports such as Bedjaia (oil refinery), Monrovia and Buchanan (iron ores and timber), and Cabinda (crude oil) reached the top 10 for the first time. Abidjan superseded Dakar due to its faster growth in comparative terms. The drop of historical ports in relative terms (they remained to hold onto the general cargo trade) is important. Moreover, the main ports of the wealthiest former colonies of the Gold Coast and Nigeria remained below three million tons (relative higher value of exported cargoes, e.g., cocoa), but greatly expanded during the 1980s due to the expansion of oil market in the region, as Nigerian figures stated. Figures for 1972 are in line with the global expansion of bulk trade (liquid and solid), which at the global scale increased from 540 million tons in 1960 to 1,654 million tons in 1972. The same goes for dry bulk commodities, which passed from 233 million tons to 505 million tons in the same period (UNCTAD, various issues). Major port reforms across the African continent began in the second half of the 1970s and funds were granted by international institutions (World Bank, International Monetary Fund, European Development Bank) or global investors from the Western, Soviet, and Arab countries.

[Table 23.3]

We have summarized some key figures on the evolution of port activity for the same test years in Table 17.3. This confirms the clear difference between North and West African ports in aggregated terms. By 1913, North Africa as a whole surpassed West Africa tenfold, even including Lagos, which was excluded due to lack of data. In 1938, differences were narrower due to the important growth, consolidation, and first phase of port sub-Saharan port reform, as seen with West Africa's $149.84 \%$ growth rate compared with $68.59 \%$ for North Africa. In 1955, the throughput ratio between North and West Africa declined to 3:1, as only Dakar reached a level comparable to that of North Africa's largest ports. In 1972, there was impressive growth in both regions, although it radically more accelerated in West Africa (1,103.49 percent) than North Africa ( 240.70 percent). This growth was directly tied to the expansion of oil activities, as explained. Individual case studies of port evolution in a number of West African ports need to be explored from a holistic perspective in order to analyze how internal evolution and the emergence of new ports modified the regional maritime networks.

Following on from this taxonomy, we could argue that historical port hierarchies marked the broader economic and institutional evolution of the analyzed regions. Yet, two distinct periods can be distinguished. Before 1955, historical port hierarchies remained unchanged and were tied to the colonization process and the continuation of long term trajectories (i.e., 
Algiers, Tunis-Goulette, Bône and Dakar). In the second half of the twentieth century, new ports with new functions emerged and throughput expanded following the global trends of seaborne trade. New specialized ports (oil ports) tied to export activities emerged and altered the regional port hierarchy, but former leading ports retained their influence as political and economic centers. Despite their relative decline, these port-cities retained their influence and urban hierarchy in terms of population, industrial clusters (e.g. Dakar) or regional redistribution of general cargoes.

Secondary ports managed to grow despite the persistent predominance of great imperial ports, notably due to their articulation of coastal shipping networks at various scales and their specific functions as micro-local hubs exporting commodities. The Moroccan port system provides an interesting example where the dominance of Casablanca was challenged by emerging ports.

As seen in Figure 23.1, the market shares of Moroccan ports between 1911 and 1972, despite missing data from 1955 to 1966, reveals an important trend of cargo concentration in Casablanca. Indeed, Casablanca itself concentrated about eighty per cent of Moroccan seaborne trade by 1930 and more than seventy per cent by 1972, despite the emergence of phosphate exports and fishing activities in the port of Saffi during the 1950s. Casablanca's hinterland permitted the evacuation of cash-crop productions (wheat, vegetables and livestock) from the rich agricultural regions of Tadla and Chaouia (Suárez and Maziane, 2014, p.78). Until the inauguration of the container terminal of Tangiers-Med in the late 1990s, most of Moroccan external trade concentrated in Casablanca. Such a concentration is typical of most national port systems in Africa, backed by the institutional choice made by the French governors during the Protectorate. In particular, the Marèchal Liautey administration decided to create an imperial port capable of confronting the British coaling station of Gibraltar.

[Figure 23.1]

The progress of shipping activities supported by the institutional environment in Casablanca contrasted with the stagnation of the "international" port of Tangiers. This port had been one of the most active port-cities on the Moroccan coast since the seventeenth century but since the signature of the Treaty of Fes (1912), it was transformed in a sort of no man's land where international interests were represented. The self-reinforcement effects of Casablanca promoted by institutional decisions and commercial expectation dynamics strengthened its predominant position. Such an artificial lock-in process causing the stagnation of Tangiers as a regional hub for northern Morocco could have been verified based on French diplomatic archives. By 1946, the French consular agent in Tangiers officially stood against further investment in the local port to avoid competition with 
Casablanca, as the international administration of the port of Tangiers was seen as a threat to the imperial private interests around general cargo redistribution in Morocco2. A closer look at inter-port shipping patterns is provided in the next section to complement our understanding of port system evolution, port hierarchies and specialization in Northwest Africa.

\section{Shipping patterns and connectivity}

Vessel movement data extracted from Lloyd's List archives were first compared with previous section figures based on tonnage in order to test their comparability. Results are relatively significant, based on a Pearson correlation coefficient (between the number of vessel calls and port throughput volume) of $0.63,0.75,0.83$, and 0.15 for the years $1910 / 1913,1935 / 1938,1951 / 1955$, and 1970/1972. The sudden decline in statistical significance in $1970 / 1972$ is directly attributable to the emergence of new bulk ports as mentioned above, with a gap between low connectivity and high volume. Less significant results were obtained when replacing vessel calls by degree centrality (i.e., the number of flows of each port with other ports). The main objective of using Lloyd's shipping data in addition to throughput data is to provide a relational perspective by mapping the evolution of Northwest Africa's maritime network between 1910 and 1970 (Figure 23.2). If the main results in terms of port hierarchies subtsnatially confirm the above discussions, they also provide new evidence on the roles and functions of regional ports internally and externally. For instance, if the St. Vincent and Canary ports often appear as major nodes based on vessel movements, they remain poorly connected to the region as a whole through secondary linkages. One exception is the year 1930, with Dakar/Las Palmas as the region's largest flow. Yet, if their intra-regional connectivity is limited, such nodes are important to ensure connectivity between North and West Africa, which would otherwise have nearly inexistent, or very minor linkages. This division between North and West was already made evident in Table 17.3 in terms of throughput growth dynamics. In fact, the region's major linkages remain internal to either North or West Africa.

Another interesting affirmation is the parallel stability and shift among the major nodes of the network over time. For instance, Algiers in North Africa had been the leading node before the 1930s and was surpassed from then onwards by Casablanca (but also Oran in 1930 and 1940). As for other larger nodes, size is reflected in local connectivity, as such ports also carry out a hub function towards their immediate neighbors. However, there are sometimes huge gaps also between size (number of vessel calls) and local connectivity, as

2 CADN. Tanger, 675POE, Carton 24. Protectorat de la RF au Maroc. Direction des Travaux Publics. Note pour le Secrétaire Générale du Protectorat, 2 September 1946. 
seen in the case of St. Vincent and the Canaries. For instance, if Casablanca clearly became North Africa's largest node, it did not increase an equivalent hub function for the Maghreb. This means that such large ports are mainly extraverted, their activity being mainly linked to external regions such as Western Europe and North America for instance.

A very distinct pattern emerged over time in West Africa, where Dakar had become the main pivotal hub for the whole sub-region, starting with a few minor linkages in 1900-1910 and gradually becoming connected to most of its neighbors in subsequent years, in a multilayered fashion (i.e. trunk lines and small linkages). We also observe that despite the predominance of Dakar, West Africa is quite polycentric, but with important shifts among the other hubs, such as Sapele $(1920,1960)$, Abo $(1940,1950)$, Douala (continuous), Takoradi (up to 1960), Freetown (1940 and 1960), Abidjan and Pointe-Noire (since the 1950s mainly), and Lagos (1970). In comparison, the limited intra-regional maritime connectivity of the Maghreb is rather specific compared with West Africa (Mohamed-Chérif and Ducruet, 2016). Some factors, such as the relatively "institutional" homogeneity among the northern territories under French colonial rule, could explain this specificity. On the other hand, institutional policies developed in the rest of territories promoted the direct linkages with overseas forelands (Debrie 2012). This trend aggravated during the decolonization processes where countries competed against each other in the international markets.

[Figure 23.2]

\section{Conclusion}

This chapter has proposed a first approach to the evolution of port networks in Northwest Africa in a historical perspective. We have shown how the resilience of great imperial ports promoted the concentration processes, which were tied to the evolution of extroverted economic structures. We found compelling evidence of a delayed port modernization process in West Africa that affected the evolution of port indicators (both throughput and connectivity). In terms of port hierarchies in the long run, we have observed how they were almost unchanged until the decade of 1950. In a context of political independences, new ports with new functions emerged but the key feature is that these ports were specialized in the export of cash-crops, mining-ores or crude oil and oil products. These ports were built to enlarge the capacity of their respective countries in terms of external trade, but in general terms the structure did not change, except with the emergence of oil ports such as Bonny or Arzew. A process of divergence between North and West Africa can be observed on the basis of both tonnage and vessel movement data, defined by increasing gaps in terms of traffic growth and intra-regional shipping connectivity. Except for this divergence, the overall 
evolution remained relatively similar during the first decades of political independences (at least on a country-level analysis), while port hierarchies tended to persist over time. Individual studies by countries must be developed in order to detect the permanent selfreinforcement effects which could help to obtain valid explanations. The unbalanced structure of trade with high value imports hampered the economic performance of these countries. In the beginning of the 1970s, the first wave of containerization reached Africa but this market did not expand as a result of technical, political and financial obstacles. Therefore, further studies must be made regarding the fully-long-term evolution of African maritime façades in order to observe the adaptation of African ports to global shifts in shipping and in particular the containerized general cargo revolution. Further research can also complement the current databases and expand the analysis by providing additional metrics in terms of centrality indicators and foreland traffic distribution.

\section{Acknowledgements}

This chapter benefited from the R\&D project HAR2015-64044-R and ULPGC-2014-01. The research leading to these results has received funding from the European Research Council under the European Union's Seventh Framework Programme (FP/2007-2013) / ERC Grant Agreement n. [313847] "World Seastems".

\section{References}

Austin G. (2015) Explaining and evaluating the cash-crop revolution in the "Peasant" colonies of tropical Africa, ca.1890-ca.1930: Beyond "Vent for Surplus". In: Akyeampong E., Bates R.H., Nunn N., Robinson J.A. (Eds.), Africa's Development in Historical Perspective, New York: Cambridge University Press, pp. 295-320.

Ba D., Diaw A.T., Leclerc G., Mering C. (2013) Analyse de la dynamique spatiale du port de Dakar de 1900 à 2009: enjeux multi-scalaires et aménagements. Cybergeo: European Journal of Geography, 635: https://cybergeo.revues.org/25773

Castillo D. (2014) The port of Dakar: technological evolution, management and commercial activity (1857-1929). In: Suárez Bosa M. (Ed.), Atlantic Ports and the First Globalisation, c.1850-1930, London: Palgrave MacMillan, pp. 90-111.

Castillo D., Valdaliso J.M. (forthcoming) A long-term perspective of the Spanish port system: path dependence, change and evolution. 
Chaves I.N., Engerman S., Robinson J.A. (2015) Reinventing the wheel: the economic benefits of wheeled transportation in early colonial British West Africa. In: Akyeampong E., Bates R.H., Nunn N., Robinson J.A. (Eds.), Africa's Development in Historical Perspective, New York: Cambridge University Press, pp. 321-365.

Debrie J. (2012) The West African port system: Global insertion and regional particularities. Echogéo, 20: https://echogeo.revues.org/13070

Dickson K.B. (1965) Evolution of seaports in Ghana: 1880-1928. Annals of the Association of American Geographers, 55: 98-111.

Direction du Port d’Abidjan (1955) Le Port d'Abidjan. Abidjan: Imprimerie de la Côte d'Ivoire.

Dobusch L., Kapeller J. (2013) Breaking new paths: Theory and method in path dependence research. Schmalenbach Business Review, 65: 288-311.

Ekberg E., Lange E., Merok E. (2012) Building the networks of trade: Perspectives in twentieth century maritime history. In: Harlaftis G., Tenold S., Valdaliso J.M. (Eds.), The World's Key Industry, London: Palgrave Macmillan, pp. 88-105.

Guerrero D., Rodrigue J.P. (2014) The waves of containerization: shifts in global maritime transportation. Journal of Transport Geography, 34: 151-164.

Hoyle B.S. (1967) The Seaports of East Africa. A Geographical Study. Nairobi: Makerere Institute of Social Research.

Kaukianen, Y. (2012) The advantages of water carriage: Scale economies and shipping, c.1870-2000. In: Harlaftis G., Tenold S., Valdaliso J.M. (Eds.), The World's Key Industry, London: Palgrave Macmillan, pp. 64-87.

Martin R., Sunley P. (2010) The place of path dependence in an evolutionary perspective on the economic landscape. In: Boschma R.A., Martin R. (Eds.), Handbook for Evolutionary Economic Geography, Chichester: Edward Elgar, pp. 62-92.

Mohamed-Chérif F.Z., Ducruet C. (2016) Regional integration and maritime connectivity across the Maghreb seaport system. Journal of Transport Geography, 51: 280-293.

Ng A.K.Y., Ducruet C. (2014) The changing tides of port geography (1950-2012). Progress in Human Geography, 38(6): 785-823.

Olukoju A. (2004) The Liverpool of West Africa. The Dynamics and Impact of Maritime Trade in Lagos, 1900-1950. New Jersey: Africa World Press. 
Olukoju A. (2014) The Port of Lagos, 1850-1929: The Rise of West Africa's Leading Port. In: Suárez Bosa M. (Ed), Atlantic Ports and the First Globalisation, c.1850-1930, London: Palgrave Macmillan, pp. 112-129.

Peterec R.J. (1967) Dakar and West African Economic Development. New York: Columbia University Press.

Rougerie G. (1950) Le port d'Abidjan. Le problème des débouchés maritimes de la Côte d'Ivoire. Sa solution lagunaire. Bulletin de I'IFAN, 12: 751-837.

Seck A. (1970) Dakar, Métropole Ouest-Africaine. Dakar: Mémoires de I'IFAN.

Suárez Bosa M. (2004) The role of the Canary Islands in the Atlantic coal route from the end of the nineteenth century to the beginning of the twentieth century: corporate strategies. International Journal of Maritime History, 16(1): 95-124.

Suárez Bosa M., Maziane L. (2014) The port of Casablanca in the first stage of the protectorate. In: Suárez Bosa M. (Ed.), Atlantic Ports and the First Globalisation, c.1850-1930, London: Palgrave Macmillan, pp. 70-89.

Taaffe E.J., Morrill R.L., Gould P.R. (1963) Transport expansion in underdevelopped countries: A comparative analysis. Geographical Review, 53: 503-529.

UNCTAD, Review of Maritime Transport, various issues.

Vance J.E. (1970) The Merchant's World. The Geography of Wholesaling. Englewood Cliffs: Prentice-Hall. 


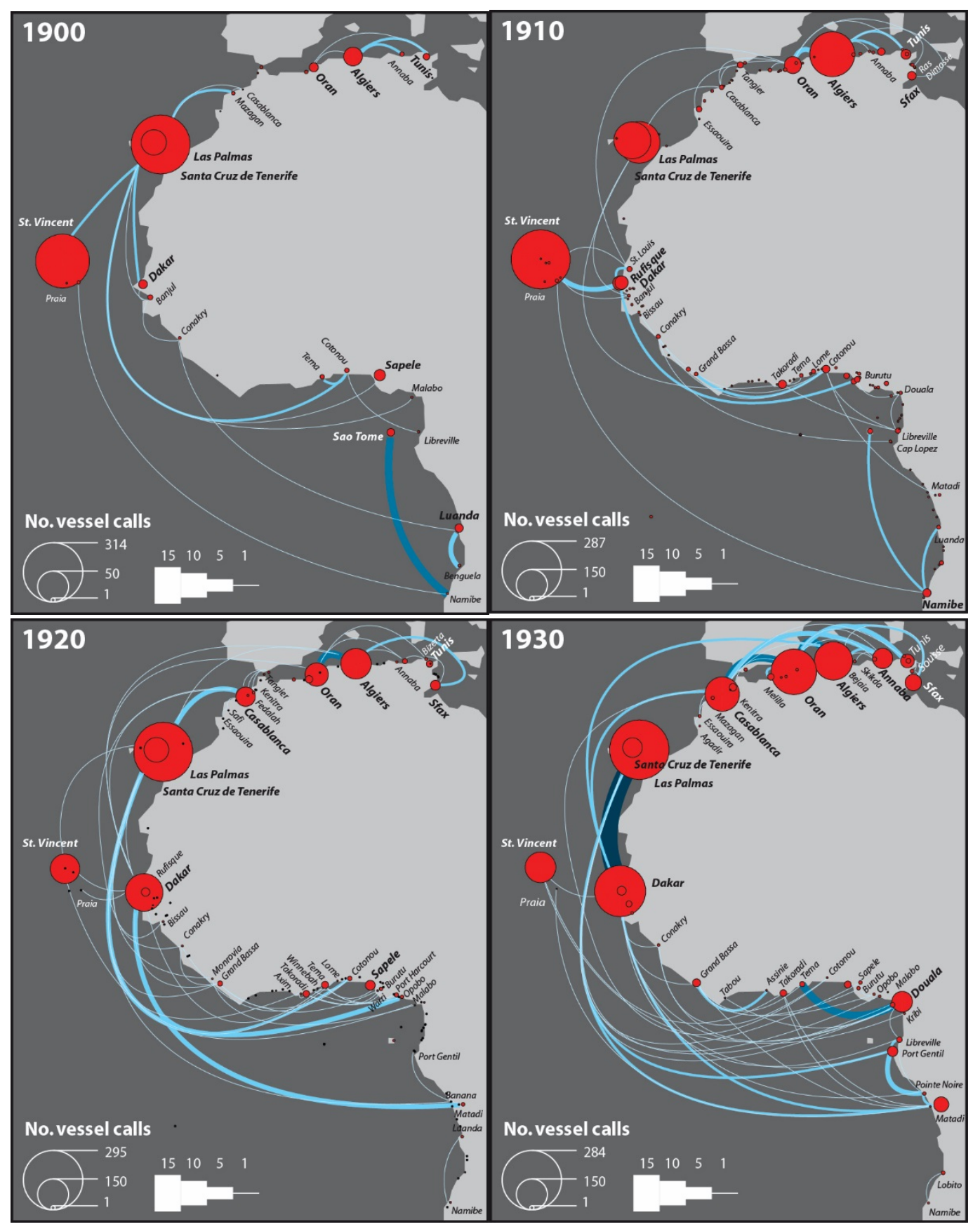

Figure 23.1: Port hierarchy and shipping routes in Northwest Africa, 1900-1970

Source: own elaboration based on Lloyd's Shipping Index 


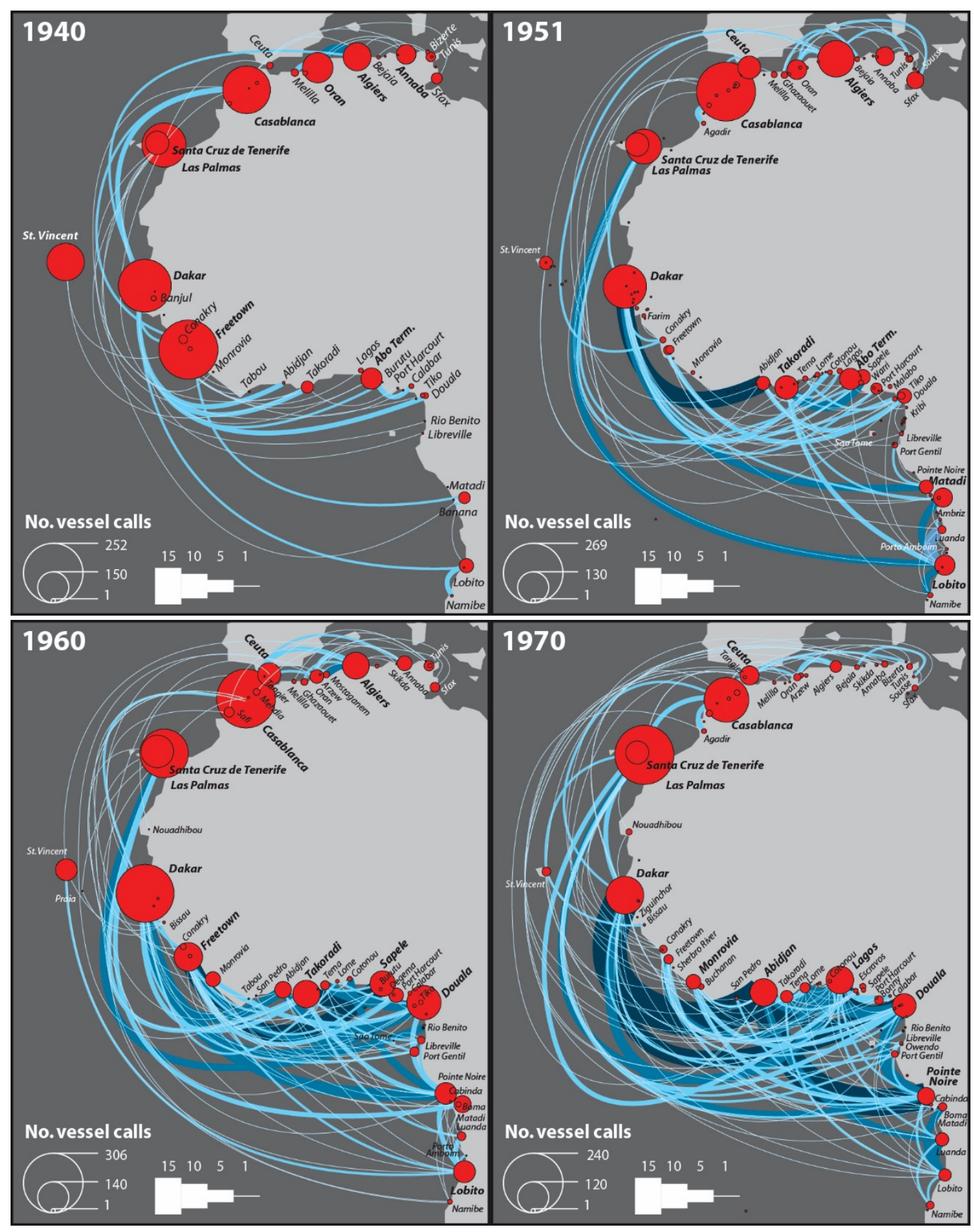

(continued) 
Table 17.1. Historical driving factors of port evolution in Northwest Africa, 1880-1972

\begin{tabular}{|c|c|c|c|c|c|}
\hline Period & $\begin{array}{l}\text { World } \\
\text { Shipping } \\
\text { Industry }\end{array}$ & $\begin{array}{l}\text { African port } \\
\text { development }\end{array}$ & $\begin{array}{l}\text { Inland } \\
\text { Transport } \\
\text { Infrastructures }\end{array}$ & $\begin{array}{l}\text { Regional } \\
\text { Economic Factors }\end{array}$ & $\begin{array}{l}\text { Regional } \\
\text { Institutional } \\
\text { Factors }\end{array}$ \\
\hline $1880-1913$ & $\begin{array}{l}\text { Last transition } \\
\text { from sail to } \\
\text { steam. British } \\
\text { merchant fleet } \\
\text { hegemony. } \\
\text { Increased } \\
\text { tonnages. } \\
\text { Maritime } \\
\text { industry } \\
\text { changes. }\end{array}$ & $\begin{array}{l}\text { Scarcely } \\
\text { developed. } \\
\text { Wharfs and } \\
\text { low-developed } \\
\text { infrastructures } \\
\text { (WA). Higher } \\
\text { port } \\
\text { performance in } \\
\text { Northern } \\
\text { Africa. }\end{array}$ & $\begin{array}{l}\text { Scarcely } \\
\text { developed. } \\
\text { Railway } \\
\text { systems (sea- } \\
\text { producer } \\
\text { regions). Poor } \\
\text { road systems. } \\
\text { Non- } \\
\text { competitive } \\
\text { waterways. }\end{array}$ & $\begin{array}{l}\text { Expansion of cash-crop } \\
\text { productions and mining } \\
\text { sectors. Growth of external } \\
\text { sectors (trade) and GDP per } \\
\text { capita. }\end{array}$ & $\begin{array}{l}\text { Scramble of } \\
\text { Africa. } \\
\text { Colonial } \\
\text { occupation. } \\
\text { Border's } \\
\text { configuration. }\end{array}$ \\
\hline 1914-1945 & $\begin{array}{l}\text { Oil-Tankers. } \\
\text { Introduction of } \\
\text { liquid fuels. } \\
\text { Increased drafts. }\end{array}$ & $\begin{array}{l}\text { Expansion of } \\
\text { port } \\
\text { infrastructures. } \\
\text { Improved } \\
\text { facilities } \\
\text { (export cash- } \\
\text { crops and } \\
\text { ores). Slow } \\
\text { mechanization. }\end{array}$ & $\begin{array}{l}\text { Railway growth } \\
\text { (until 1930s). } \\
\text { Road transport } \\
\text { concurrence } \\
\text { (wagons) (late } \\
\text { 1930s). }\end{array}$ & $\begin{array}{l}\text { Cash-crop prices crisis. Urban } \\
\text { growth and regional } \\
\text { metropolization of imperial } \\
\text { port-cities. Drop of GDP per } \\
\text { capita. }\end{array}$ & $\begin{array}{l}\text { Development } \\
\text { of colonial } \\
\text { institutional } \\
\text { model. } \\
\text { Definitive } \\
\text { occupation } \\
\text { and control of } \\
\text { the inner-lands } \\
\text { (WA). } \\
\text { Introduction of } \\
\text { modern port } \\
\text { management } \\
\text { models. }\end{array}$ \\
\hline $1946-1960$ & $\begin{array}{l}\text { Post-war } \\
\text { shipping boom. } \\
\text { Increased } \\
\text { tonnages and } \\
\text { drafts. Scale } \\
\text { economies and } \\
\text { Super-Tankers } \\
\text { (late 1950s). } \\
\text { Beginnings of } \\
\text { containerization. }\end{array}$ & $\begin{array}{l}\text { New port } \\
\text { functions. Port } \\
\text { expansion } \\
\text { (WA) (Suez } \\
\text { crisis). }\end{array}$ & $\begin{array}{l}\text { Decline of } \\
\text { railways. } \\
\text { Increased } \\
\text { importance of } \\
\text { road transports. } \\
\text { Expansion of } \\
\text { the paved roads. }\end{array}$ & $\begin{array}{l}\text { Post-war inflation. Stagnation of } \\
\text { cash-crop productions. Transfer } \\
\text { of transport-economic } \\
\text { infrastructures. Relative weak } \\
\text { growth of GDP per capita. }\end{array}$ & $\begin{array}{l}\text { Socio- } \\
\text { economic } \\
\text { instability and } \\
\text { decline of } \\
\text { colonial rule. } \\
\text { North-African } \\
\text { revolutions. } \\
\text { New } \\
\text { management } \\
\text { models in port } \\
\text { infrastructures. }\end{array}$ \\
\hline 1960-1972 & $\begin{array}{l}\text { First wave of } \\
\text { containerization. } \\
\text { Expansion of } \\
\text { bulk trade }\end{array}$ & $\begin{array}{l}\text { Relative } \\
\text { stagnation of } \\
\text { old colonial } \\
\text { ports. }\end{array}$ & $\begin{array}{l}\text { Financial } \\
\text { troubles and } \\
\text { weak } \\
\text { investments on }\end{array}$ & $\begin{array}{l}\text { Massive public investments } \\
\text { and nationalization of } \\
\text { productive sectors. } \\
\text { Increased international }\end{array}$ & $\begin{array}{l}\text { New pro- } \\
\text { socialist } \\
\text { States. } \\
\text { Nationalism }\end{array}$ \\
\hline
\end{tabular}




\begin{tabular}{|c|c|c|c|c|}
\hline $\begin{array}{l}\text { (crude oil and } \\
\text { oil products). } \\
\text { Free registry } \\
\text { countries. }\end{array}$ & $\begin{array}{l}\text { Emergence of } \\
\text { "new ports" } \\
\text { and functions. } \\
\text { Weak } \\
\text { introduction of } \\
\text { container } \\
\text { technologies. } \\
\text { Technical gap } \\
\text { and lack of } \\
\text { investments. }\end{array}$ & $\begin{array}{l}\text { roads. Crisis of } \\
\text { railway } \\
\text { systems. } \\
\text { Limited inland } \\
\text { integration. }\end{array}$ & $\begin{array}{l}\text { concurrence on raw } \\
\text { materials. Slow growth of } \\
\text { GDP per capita. }\end{array}$ & $\begin{array}{l}\text { and regional } \\
\text { rivalries. } \\
\text { Political } \\
\text { instability and } \\
\text { financial } \\
\text { crisis. } \\
\text { Postcolonial } \\
\text { affairs. }\end{array}$ \\
\hline
\end{tabular}

Source: Series of GDP obtained from Maddison Project. Made by the authors Note: NA (North Africa); WA (West Africa). 
Table 17.2

Top 20 Rank of port throughput in Northwest Africa for 1913, 1938, 1955 and 1972 (in harbor tons)

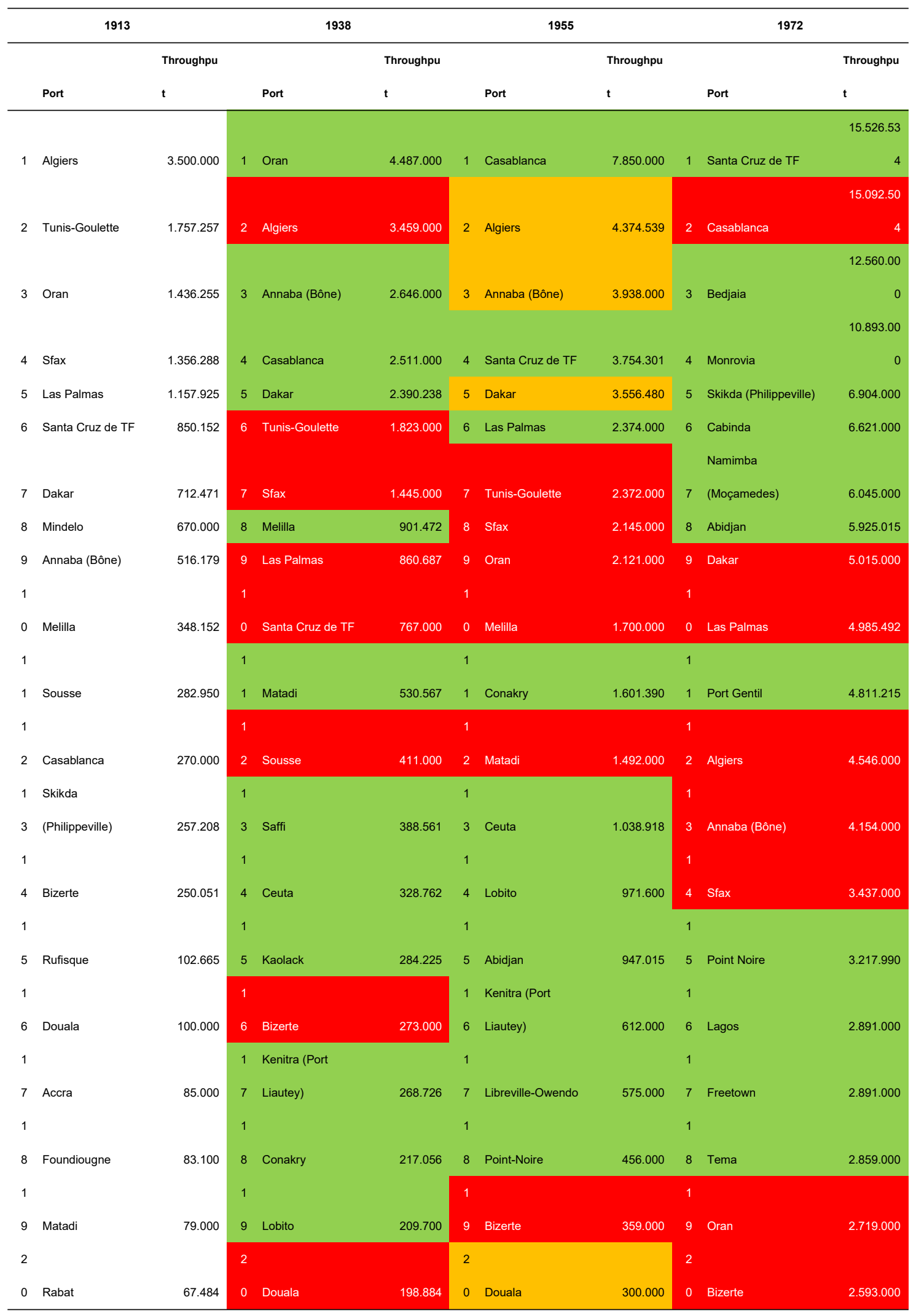


Note: Figures for Nigeria, Gold Coast and Sierra Leone for early periods before 1972 are not yet completed. The same goes for Conakry by 1972 . So, this rank must be considered as provisional and relatively representative. Sample of ports for: $1913 n=32$; $1938 n=37 ; 1955 n=$ 29; $1972 \mathrm{n}=51$.

Source: African Ports Historical Database (forthcoming). Author's elaboration.

Table 17.3

Throughput analysis in North and West Africa (1913, 1938, 1955 and 1972)

\begin{tabular}{|c|c|c|c|c|c|c|c|}
\hline \multicolumn{8}{|c|}{ North Africa } \\
\hline \multicolumn{2}{|l|}{1913} & \multicolumn{2}{|c|}{1938} & \multicolumn{2}{|c|}{1955} & \multicolumn{2}{|l|}{1972} \\
\hline Ports & & Ports & & Ports & & Ports analyzed & \\
\hline analyzed (n) & 20 & analyzed (n) & 19 & analyzed (n) & 16 & (n) & 24 \\
\hline Total & 12.35 & Total & 20.83 & Total & 34.52 & Total & 84.45 \\
\hline Throughput & 8.490 & Throughput & 5.989 & Throughput & 9.994 & Throughput & 9.463 \\
\hline & & Growth rate & & Growth rate & & Growth rate & 144.5 \\
\hline Growth rate & $\mathrm{n} / \mathrm{a}$ & $(1913-38)$ & 68.59 & $(1938-55)$ & 65.72 & $(1938-55)$ & 9 \\
\hline Throughput & 617.9 & Throughput & 1.096 & Throughput & 2.158 . & & 3.519 . \\
\hline avg. & 25 & avg. & 631 & avg. & 125 & Throughput avg. & 144 \\
\hline Throughput & 263.6 & Throughput & 411.0 & Throughput & 1.910 . & Throughput & 2.936. \\
\hline median. & 04 & median. & 00 & median. & 500 & median. & 570 \\
\hline Ports $>$ & & Ports $>$ & & Ports $>$ & & & \\
\hline 1.000 .000 & & 2.000 .000 & & 3.000 .000 & & Ports $>$ & \\
\hline tons & 5 & tons & 4 & tons & 4 & 10.000 .000 tons & 3 \\
\hline & & Ports $>$ & & Ports $>$ & & & \\
\hline Ports $>$ & & 1.000 .000 & & 2.000 .000 & & Ports $>$ & \\
\hline 500.000 tons & 7 & tons & 6 & tons & 8 & 4.000 .000 tons & 7 \\
\hline
\end{tabular}

\begin{tabular}{|c|c|c|c|c|c|c|c|}
\hline \multicolumn{8}{|c|}{ West Africa } \\
\hline \multicolumn{2}{|c|}{1913} & \multicolumn{2}{|l|}{1938} & \multicolumn{2}{|c|}{1955} & \multicolumn{2}{|l|}{1972} \\
\hline Ports & & Ports & & Ports & & Ports analyzed & \\
\hline analyzed (n) & 12 & analyzed (n) & 18 & analyzed (n) & 13 & (n) & 27 \\
\hline Total & 1.970 & Total & 4.922. & Total & 10.67 & Total & 64.49 \\
\hline Throughput & 138 & Throughput & 200 & Throughput & 6.585 & Throughput & 8.507 \\
\hline & & Growth rate & 149.8 & Growth rate & 116.9 & Growth rate & 504.1 \\
\hline Growth rate & $\mathrm{n} / \mathrm{a}$ & (1913-38) & 4 & $(1938-55)$ & 0 & $(1938-55)$ & 1 \\
\hline Throughput & 164.1 & Throughput & 273.4 & Throughput & 821.2 & & 2.388 . \\
\hline avg. & 78 & avg. & 56 & avg. & 76 & Throughput avg. & 834 \\
\hline Throughput & 81.05 & Throughput & 130.8 & Throughput & 456.0 & Throughput & 1.966. \\
\hline median. & 0 & median. & 50 & median. & 00 & median. (top.20) & 268 \\
\hline Ports $>$ & & Ports $>$ & & Ports $>$ & & & \\
\hline 1.000 .000 & & 2.000 .000 & & 3.000 .000 & & Ports $>$ & \\
\hline tons & 0 & tons & 1 & tons & 1 & 10.000 .000 tons & 1 \\
\hline
\end{tabular}


Ports $>$

Ports $>$

Ports $>$

1.000 .000

2.000 .000

Ports >

500.000 tons

2 tons

1 tons

$1 \quad 4.000 .000$ tons

6

Sources: African Ports Historical Database (forthcoming). Author's elaboration. 